\title{
Multislot Fishway Improves Entrance Performance and Fish Transit Time over Vertical Slots
}

\author{
Filipe Romão ${ }^{1, * \mathbb{D}}$, Ana L. Quaresma ${ }^{1} \mathbb{D}$, José M. Santos ${ }^{2} \mathbb{D}$, Susana D. Amaral ${ }^{2} \mathbb{D}$, Paulo Branco ${ }^{2} \mathbb{D}$ and \\ António N. Pinheiro ${ }^{1}$ (D)
}

1 CERIS-Civil Engineering for Research and Innovation for Sustainability, Técnico, University of Lisbon, Avenida Rovisco Pais, 1049-001 Lisboa, Portugal; analopesquaresma@tecnico.ulisboa.pt (A.L.Q.); antonio.pinheiro@tecnico.ulisboa.pt (A.N.P.)

2 Forest Research Centre, School of Agriculture, University of Lisbon, Tapada da Ajuda, 1349-017 Lisboa, Portugal; jmsantos@isa.ulisboa.pt (J.M.S.); samaral@isa.ulisboa.pt (S.D.A.); pjbranco@isa.ulisboa.pt (P.B.)

* Correspondence: filipe.romao@tecnico.ulisboa.pt; Tel.: +351-9-1861-2529

Citation: Romão, F.; Quaresma, A.L.; Santos, J.M.; Amaral, S.D.; Branco, P.; Pinheiro, A.N. Multislot Fishway Improves Entrance Performance and Fish Transit Time over Vertical Slots. Water 2021, 13, 275. https://doi.org/ $10.3390 /$ w13030275

\section{Academic Editor:}

Bommanna Krishnappan

Received: 2 January 2021

Accepted: 21 January 2021

Published: 24 January 2021

Publisher's Note: MDPI stays neutral with regard to jurisdictional claims in published maps and institutional affiliations.

Copyright: (c) 2021 by the authors. Licensee MDPI, Basel, Switzerland. This article is an open access article distributed under the terms and conditions of the Creative Commons Attribution (CC BY) license (https:// creativecommons.org/licenses/by/ $4.0 /)$.

\begin{abstract}
Pool-type fishways have been increasingly tested to improve fish passage performance and minimize migration delays. Designing cost-effective fishways is essential for a trade-off between water uses and successful longitudinal connectivity restoration. The multislot fishway (MSF) concept, which operates with 30-50\% lower discharge than a vertical slot fishway (VSF), was recently developed. This study assessed and compared the entrance performance (entrance time; entry efficiency) and transit times of two cyprinids for VSFs and MSFs. Four configurations, with the same structural characteristics (slope; water depth; head drop; pool width and depth), operating with different discharges (Q), were tested (VSF 1: $Q=112 \mathrm{~L} \cdot \mathrm{s}^{-1}$; VSF 2: $\mathrm{Q}=80 \mathrm{~L} \cdot \mathrm{s}^{-1}$; MSF 1: $\mathrm{Q}=58 \mathrm{~L} \cdot \mathrm{s}^{-1}$; MSF 2: $\mathrm{Q}=37 \mathrm{~L} \cdot \mathrm{s}^{-1}$ ). Hydrodynamics characterization was performed using a numerical model. Results showed that entry efficiency was higher in MSFs than in VSFs, while entrance time and transit time were overall lower. Numerical modelling revealed that velocities were around 30\% lower in MSFs, and turbulence could reach a difference of around $70 \%$ in Reynolds shear stress and $50 \%$ in turbulent kinetic energy. Overall, MSFs can be considered as a cost-effective fishway solution that can balance the trade-offs between divergent interests in water uses.
\end{abstract}

Keywords: transit time; vertical slot fishway; multislot fishway; cyprinids; turbulence; discharge; cost-effective

\section{Introduction}

Globally, river fragmentation and dam construction represent a major threat to freshwater ecosystems biodiversity and functioning [1]. In Europe, recent estimates indicate the presence of over one million barriers causing cumulative impacts on freshwater organisms [2]. Over the course of the years, pool-type fishways were considered the main technical mitigation solution to restore longitudinal connectivity for fish species in regulated rivers worldwide [3-5]. When correctly designed, these structures allow moving fish to have a pathway and, thus, allow the genetic flow between fish populations [6]. As barriers and correspondent impoundments will continue to expand in a near future, to meet the rising demand for water (hydropower, irrigation, and drinking water) [7], new engineering solutions are deemed necessary to increase passage efficiency and reduce the transit time and the flow allocated to the fish passage [8-10]. Among the several pool-type fishways (i.e., pool-type with bottom orifices and/or notches, or slots) the vertical slot fishway (VSF) is considered a reliable option for managers who wish to re-connect river segments and set a passageway for moving fish [11,12]. VSF is usually regarded as one of the best technical fishway option, because (i) fish can move between pools at their preferred depth [13]; (ii) they can handle significant variations in the up-and-downstream water levels, making them suitable to undergo variations in river discharge [14]; (iii) they are 
less prone to clogging with debris and sediments than pool-type fishways with orifices and/or notches [11,15]. However, when compared with other fish passages equipped with orifices and/or notches, VSFs require higher discharges $(\mathrm{Q})$, which inflates their water related operational costs [16]. To reduce these costs, the multislot fishway (MSF) stands out as a recent design that provides a cost-effective solution that gathers some of the best features of VSFs but operates with a lower discharge [17]. In fact, this type of facility may operate with 30 to $50 \%$ lower discharge compared to widely used VSFs while maintaining its effectiveness for cyprinid species [10].

Two central aspects should be considered in the development process of designing a fishway for multi-species, as they play a key role in maximizing its performance: the biology and ecology of the target species (i.e., swimming mechanics, physiologic thresholds, reproductive strategy, motivation to migrate) and the hydraulic conditions of the facility (i.e., the slope, pool geometry, head drop, discharge, turbulence, flow velocities) $[3,18]$. Ideally, a holistic fishway should serve a wide range of species, ensuring effective negotiation with minimal physiological stress and energy expenditure, allowing fitness enhancement or maintenance $[19,20]$. Therefore, fish transit time (the time to successfully ascend the fishway), the entrance time (the time to enter the first pool), and entry efficiency are determinant metrics to characterize the performance of a fishway design. Hence, entrance and transit time should be as low as possible to enable fish to continue their migratory movements and access habitats for growth, refuge, and reproduction [21], as fish frequently need to overcome several obstacles to reach their vital areas [22].

River systems in the Iberian Peninsula are mainly characterized by Mediterranean climatic conditions with strong inter-seasonal and inter-annual variability in river flows [23]. These systems exhibit periods with high flows in winter followed by dry or very dry summers. However, due to the inter-annual rainfall variability, the dry season can extend longer and consequently result in long supra-seasonal droughts [24]. For this reason, water scarcity is a recurrent scenario in these regions and restoration designers and managers should be encouraged to develop and apply cost-effective fish passage solutions. Furthermore, drought scenarios are expected and will increase inevitably in the near future due to climate change, reinforcing the need to use water-effective and resilient fish passage systems $[25,26]$. The Iberian Peninsula freshwater fish assemblages are composed of a considerable number of endemic species. Currently, around $52 \%$ of these species are cataloged as threatened, according to the Red List of the International Union for Conservation of Nature [27]. The large number of endemic species collectively with the extensive human impacts in this region (e.g., dams, water abstraction, and pollution) is the main cause of this worrying scenario [28]. Therefore, the reestablishment of the longitudinal connectivity through fishways is paramount to allow Iberian fish assemblages to survive and thrive, as endorsed by the European legislation, the Water Framework Directive (WFD) [29,30].

In the present study, the entrance performance (i.e., entrance time and entry efficiency) and the transit time of the Iberian barbel (Luciobarbus bocagei, Steindachner, 1864) and the South Iberian chub (Squalius pyrenaicus, Günther, 1868), two endemic Iberian cyprinids with distinct ecological traits and swimming capacities, was assessed in a full-scale model of a fishway. Four different configurations of fishways (with the same structural characteristics (i.e., slope, water depth, head drop, pool width and depth) were tested-two commonly used VSF and two MSF configurations-with the objective of determining which configuration enhances the passage performance of both species. To characterize the hydrodynamics of the tested configurations, numerical modelling was conducted using the computational fluid dynamics (CFD) commercial software FLOW-3D ${ }^{\circledR}$. In this study, we predict that (i) entrance performance is higher (i.e., lower entrance time and higher entrance efficiency) in MSFs than in VSFs and that (ii) transit time to successful negotiation of the fishway is lower for MSFs than for VSFs. 


\section{Materials and Methods}

\subsection{Experimental Facility}

Experiments were conducted between spring 2015 and autumn 2016 in a flume with the following dimensions: $10 \mathrm{~m}$ length; $1 \mathrm{~m}$ width; $1.2 \mathrm{~m}$ height located at the National Laboratory for Civil Engineering (LNEC) in Lisbon, Portugal. A full-scale model of a fishway was installed in the flume, equipped with lateral glass walls, which allowed the continuous tracking of fish movements. The flow supplied to the fishway was provided through a pump and measured by an electromagnetic flow-meter (precision of $0.4 \%$ ) installed in a recirculation pipe. The discharge was regulated through a pump frequency controller, and the water level was adjusted by a slot gate in the downstream tank with the following dimensions: $4 \mathrm{~m}$ length; $3 \mathrm{~m}$ width; $4 \mathrm{~m}$ height. Further details about the experimental apparatus are provided in Romão et al. [13].

Four different configurations of fishways were assembled in the flume-two commonly used VSF (VSF 1 and VSF 2) and two MSF configurations (MSF 1 and MSF 2). VSF configurations had a hydraulic head drop per pool $(\Delta \mathrm{H})$ of $0.16 \mathrm{~m}$ and were based on designs proposed by Rajaratnam et al. [31] —VSF 1 included a central and lateral baffle, while VSF 2 included only a lateral baffle (Figure 1a,b). The MSFs presented a twofold number of slots compared to the VSFs and were based on the multislot fishway concept, originally developed by Tauber and Mader [32], also designated as Enature [17,33]. MSF 1 (Figure 1c) presented two vertical slots in each pool, while MSF 2 (Figure 1d) included a combined solution that incorporated a vertical slot and a bottom orifice. Since MSFs presented two slots per pool, the $\Delta \mathrm{H}=0.16 \mathrm{~m}$ was divided by two, becoming approximately $0.08 \mathrm{~m}$ per slot. The MSF 1 was selected based on numerical model results reported by Quaresma et al. [34], which simulated suitable flow conditions based on Iberian fish species critical swimming speed thresholds. Therefore, this configuration was assembled in the flume to assess the passage performance of Iberian cyprinids, as it represents a theoretical optimal design.

In all the configurations, the mean water depth in the pools was $0.80 \mathrm{~m}$; the fishway slope was set to $8.5 \%$, and the cross-walls were made with plywood (0.022 $\mathrm{m}$ thick). Each fishway was composed of 6 pools with a total length of $1.85 \mathrm{~m}$ and $1 \mathrm{~m}$ width (Table 1 ). All the vertical slots were $0.10 \mathrm{~m}$ wide and the bottom orifices used in MSF 2 were 0.40 $\mathrm{m}$ high and $0.1 \mathrm{~m}$ wide. By fixing these parameters in all configurations, the operating discharge had to be different (range: $37-112 \mathrm{~L} \cdot \mathrm{s}^{-1}$; Table 1) in order to attain the hydraulic equilibrium in vertical slot fishways under uniform flow condition [11,35].

Table 1. Summary of the fishway configurations tested. Q, discharge; Pv, volumetric dissipation power; Cd, discharge coefficient; $\mathrm{L}$, pool length; $B$, pool width; $b$, vertical slot width; $\Delta H$, head drop per pool; $h_{m}$, pool mean water depth; I, fishway slope. VSF-vertical slot fishway; MSF-multislot fishway. $\triangle \mathrm{H}$ was $0.16 \mathrm{~m}$; however, since the MSF has two slots per pool compared to a VSF, this head drop is divided into two, becoming approximately $0.08 \mathrm{~m}$ per slot.

\begin{tabular}{|c|c|c|c|c|c|c|c|c|c|}
\hline & $Q\left(L \cdot s^{-1}\right)$ & $\operatorname{Pv}\left(W \cdot m^{-3}\right)$ & $\mathrm{Cd}(-)$ & $L(m)$ & B (m) & $\mathrm{b}(\mathrm{m})$ & $\Delta \mathbf{H}(\mathrm{m})$ & $\mathbf{h}_{m}(\mathbf{m})$ & i (\%) \\
\hline VSF 1 & 112 & 114 & 0.71 & \multirow{4}{*}{1.85} & \multirow{4}{*}{1.00} & \multirow{4}{*}{0.10} & \multirow{4}{*}{0.16} & \multirow{4}{*}{0.8} & \multirow{4}{*}{8.5} \\
\hline VSF 2 & 80 & 83 & 0.52 & & & & & & \\
\hline MSF 1 & 58 & 59 & 0.53 & & & & & & \\
\hline MSF 2 & 37 & 38 & 0.34 & & & & & & \\
\hline
\end{tabular}


(a)

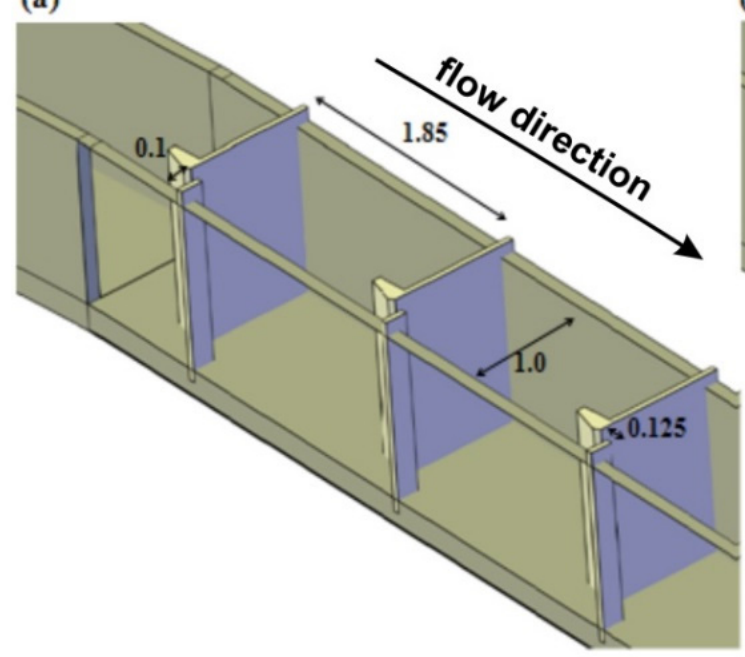

(c)

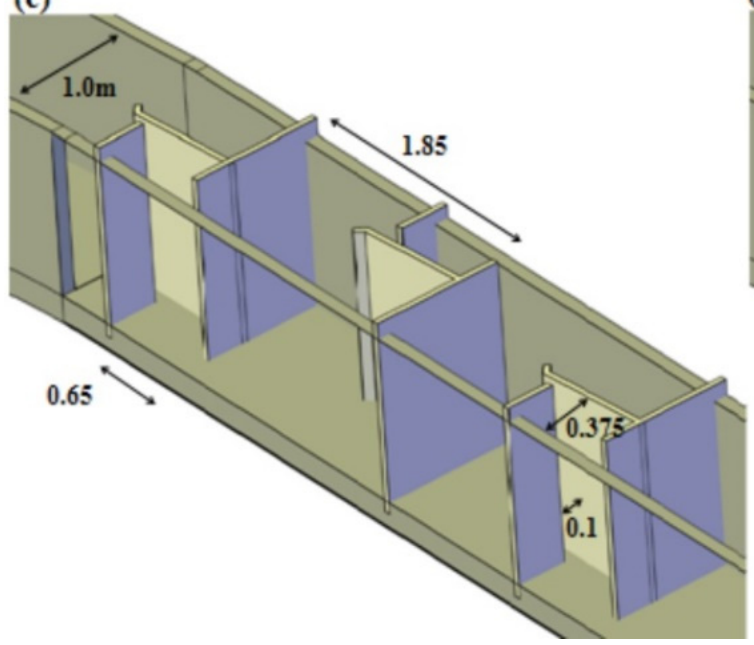

(b)

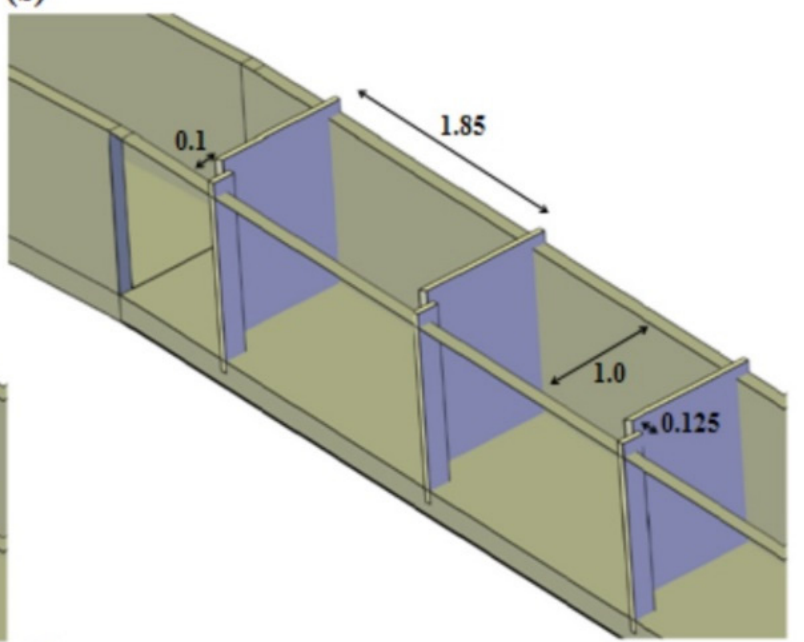

(d)

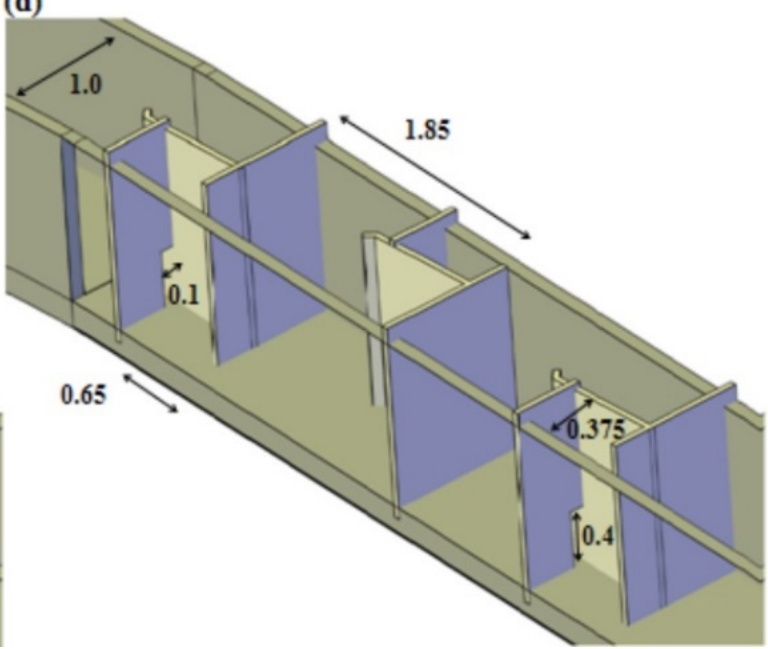

Figure 1. Fishway configurations tested (slope of $8.5 \%$ ). (a) Vertical slot fishway (VSF 1)—discharge (Q) $=112 \mathrm{~L} \cdot \mathrm{s}^{-1}$; (b) VSF 2-Q $=80 \mathrm{~L} \cdot \mathrm{s}^{-1}$; (c) multislot fishway (MSF 1)-Q $=58 \mathrm{~L} \cdot \mathrm{s}^{-1}$; (d) MSF 2-Q = $37 \mathrm{~L} \cdot \mathrm{s}^{-1}$ ) (dimensions in meters).

\subsection{Fish Capture}

Tested fish were previously caught with electric fishing in a small Atlantic coastal river in central Portugal, the Lizandro River. The fish collection was performed with wadable electrofishing gear (IG-200, Hans Grassl, Schönau am Königsee, Germany) according to the protocol adopted by the European Committee for Standardization [36]. After being caught, fish were directly transported to the laboratory holding tanks using a fish-transport box (Hans Grassl, Schönau am Königssee, Germany, 190 L) with river water and external aeration (ELITE, Holm, Germany). In each sampling event, 50 fish were collected and transported to the laboratory facilities. The holding tanks with $700 \mathrm{~L}$ capacity were equipped with high-performance mechanical and biological filtration (FX5, Fluval, Quebec, Canada) with a turnover rate of $2300 \mathrm{~L} \cdot \mathrm{h}^{-1}$. Fish were allowed to recover from the fishing- and handling-induced stress for a period of $48 \mathrm{~h}$ and were not fed during this stage. Food was provided daily to the tested fish in the holding tanks with Tetra Pond sticks. Water quality was regularly monitored with a multiparametric probe (HANNA, HI 9812-5, Wensojit, RI, USA); mean $( \pm \mathrm{SD})$ temperature, $\mathrm{pH}$, and conductivity were, respectively: $22.1 \pm 1.5^{\circ} \mathrm{C}$, $7.6 \pm 0.4,182 \pm 23.2 \mu \mathrm{S} \cdot \mathrm{cm}^{-1}$.

\subsection{Fish Experiments}

All procedures involving animal handling, including capture, housing, and fish passage experiments, were carried out in strict compliance with European standards (Directive 
2010/63/EU) and Portuguese legislation (Decree-Law 113/2013, 7th August, article 35, n. ${ }^{\circ}$ 5, transposing the European Directive for animal experimentation). Permits regarding fish capture, handling, transportation, and holding were issued by the Portuguese Institute for Conservation of Nature and Forests (ICNF), which also authorized keeping the fish in captivity, in accordance with the methodology presented in this study. Thus, all the necessary procedures to complete this study were performed with minimum handling stress. No fish were sacrificed for the purpose of this study.

Fish experiments were performed with a total of 200 wild-caught fish: 100 barbels and 100 chubs ( 25 individuals of each species were used in each fishway configuration tested). These numbers were chosen in a balanced way to harmonize ethical issues with the scientific and management knowledge gains and preformed with acceptance of the national authorities ensuring animal welfare, according to the international recommendations for replacement, refinement, and reduction in animals in research (3Rs), expressed in the European Directive 2010/63/EU, and transposed into Portuguese national legislation (DL 113/2013 and DL 1/2019). Those species were selected because they were considered representative of medium-sized potamodromous benthic cyprinids (Luciobarbus sp.) and small-size water-column-oriented resident species (Squalius sp.), occurring in several Iberian and European rivers [27]. Chubs presented a total length $( \pm \mathrm{SD})$ of $12.8 \pm 0.7 \mathrm{~cm}$ and a total body mass $( \pm \mathrm{SD})$ of $23.7 \pm 2.8 \mathrm{~g}$, and barbels presented, respectively, $20.1 \pm 1.9 \mathrm{~cm}$ and $88.5 \pm 33.2 \mathrm{~g}$. Each trial was composed of a school of five adult fish with a similar total length, to avoid bias in the swimming performance [37,38]. Additionally, to avoid possible bias in the outcome of the experiments, as a result of learning-based effects [39], each fish was used only once in the study. Trials began with an acclimation period to the experimental facility of $30 \mathrm{~min}$. For this, fish were first placed in the downstream end of the fishway in an acclimation area (dimensions: $0.9 \mathrm{~m}$ length and $1 \mathrm{~m}$ width), which was set with two mesh panels, allowing fish to get acquainted with the flow conditions of each configuration tested. After the acclimation period, the upstream mesh panel was lifted and individuals could move freely through the fishway for a period of $90 \mathrm{~min}$. Water quality was monitored during the trials, mean $( \pm \mathrm{SD})$ temperature, $\mathrm{pH}$, and conductivity were $22.1 \pm 1.3^{\circ} \mathrm{C}, 7.9 \pm 0.4,165.5 \pm 18.7 \mu \mathrm{S} \cdot \mathrm{cm}^{-1}$, respectively.

Fish behavior was recorded with the assistance of three independent observers for the following passage metrics: (i) entrance time (the time for the fastest fish of each school to pass the first slot); (ii) entry efficiency (the total number of fish passing through the first slot divided by the number of corresponding attempts to pass-an attempt was only registered when fish were standing towards the main jet passing through the slot and simultaneously exhibiting sprint movements); (iii) transit time (the time of the fastest fish in each school to cross the most upstream slot and reach the upstream end of the fishway). Video recording was performed (video camera: GoPro HERO5 positioned laterally in the first pool of the fishway) to analyze fish entrance movements and entry efficiency. After experimentation, fish were then released at their natural environment.

\subsection{Data Analysis}

Data analysis was conducted using permutational multivariate analysis of variance (PerMANOVA) using the Euclidean distance to examine interspecific and intraspecific significant differences between the barbel and chub passage metrics (entrance time, entry efficiency, and transit time) between the four fishway configurations tested (VSF 1, VSF 2, MSF 1, MSF 2), and particularly between VSF and MSF. This statistical analysis is based on permutations tests that directly partition the variation in a distance matrix according to Euclidean distances or non-Euclidean-embeddable dissimilarity measures [40]. This statistical approach is considered a robust non-parametric method, which enables significance tests even for small size samples [41]. The analysis was computed using the package PERMANOVA for PRIMER + v6.0 [42]. 


\subsection{Hydrodynamic Characterization}

A commercial CFD software (FLOW-3D ${ }^{\circledR}$ ) was used to perform the flow field numerical modelling of the tested fishway configurations. FLOW-3D ${ }^{\circledR}$ solves the governing equations of fluid motion in a Cartesian staggered grid using finite volumes method to obtain transient, three-dimensional solutions. The computational domain was discretized using multi-block grids to optimize the mesh according to the simulated fishway configurations, which were generated in AutoCAD and were imported into the code as stereolithography (STL) files. The large-eddy simulation (LES) model and the second order monotonicity preserving method were used. The acceleration of gravity was applied in the negative $z$-direction and in the positive $x$-direction so that the $x$-axis was parallel to the fishway bottom. The upstream and downstream boundaries were specified as pressure boundary conditions, based on the water depths observed experimentally. The side-walls and the bottom were modelled as no-slip boundaries, and, at the top, a symmetry boundary condition (zero value for normal velocity, zero gradients for the other quantities) was applied. The initial pressure was set to the atmospheric pressure. Firstly, the model was used to characterize the hydrodynamics of 3 of the 4 tested configurations (VSF 1, VSF 2, and MSF 1) in Quaresma et al. [34], where a complete outline of the model development, verification, and validation can be found. To validate the numerical model results, measurements were performed using an Acoustic Doppler Velocimeter (ADV) to characterize flow velocities. These measurements were performed for both VSF 1 and VSF 2 configurations in the second pool (in the upstream direction) in two planes parallel to the flume bottom (112-110 sampling points in each plane) at two flow depths: $0.50 \mathrm{~m}$ and $0.625 \mathrm{~m}$, corresponding, to $62.5 \%$ and $78 \%$ of $\mathrm{hm}$, respectively (further details concerning the ADV measurements are presented in Romão et al. [13]). Additionally, mean water depth in the pools, the hydraulic head drop $(\Delta \mathrm{h})$, and discharge were measured in each configuration tested in the physical model. Comparisons between the values observed in measurements performed in the physical model and numerical model show relative differences (computed by dividing the difference between numerical and experimental values by the latter ones) lower than $5 \%$. The discharge observed in the physical model was VSF $1-110 \mathrm{~L} \cdot \mathrm{s}^{-1}$; VSF 2-81 L's ${ }^{-1}$; MSF 1-56 L's ${ }^{-1}$; MSF 2-36 L's ${ }^{-1}$, while in the numerical model,

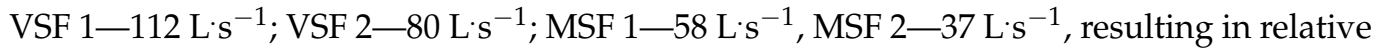
differences of $2.3,-1.3,3.3,2.8 \%$, respectively. Regarding the pool mean water depth, the values observed in the physical model were VSF $1-0.80 \mathrm{~m}$; VSF 2-0.80 m; MSF $1-0.80 \mathrm{~m}$; MSF $2-0.80 \mathrm{~m}$, while in the numerical model, VSF $1-0.80 \mathrm{~m}$; VSF $2-0.81 \mathrm{~m}$; MSF $1-0.83 \mathrm{~m}$; MSF $2-0.81 \mathrm{~m}$, resulting in relative differences of $0.1,1.8,4.2,-1.2 \%$, respectively. These values are in line with the ones found for the other configurations [34], showing that the model accurately reproduced the flow fields under analysis (further details concerning the numerical model verification and validation are presented in Quaresma et al. [34]).

\section{Results}

The entrance time, the entry efficiency, and transit time for both species are shown in Figure 2. Regarding the entrance time, pairwise comparisons performed with a PERMANOVA analysis, using the fishway configuration as a four-level fixed factor (VSF 1; VSF 2; MSF 1; MSF 2), evidenced significant differences in the entrance time (Figure 2a) of both species. For barbel, differences occurred between VSF 1 (median time \pm SE: $14 \pm 6 \mathrm{~min}$ ) and MSF 2 (median time \pm SE: $3 \pm 1 \mathrm{~min})(\mathrm{t}=2.48 ; p=0.02$ ); VSF 2 (median time $\pm \mathrm{SE}$ : $12 \pm 2 \mathrm{~min}$ ) and MSF $2(\mathrm{t}=2.86 ; p=0.02) ; \operatorname{MSF} 1$ (median time \pm SE: $12 \pm 4 \mathrm{~min})$ and MSF $2(t=2.85 ; p=0.02)$. Correspondingly, chub entrance time was different between VSF 1 (median time \pm SE: $6 \pm 4 \mathrm{~min}$ ) and MSF 2 (median time \pm SE: $1 \pm 0 \mathrm{~min})(\mathrm{t}=2.08 ; p=0.01)$ VSF 2 (median time \pm SE: $19 \pm 4 \mathrm{~min}$ ) and MSF 1 (median time \pm SE: $2 \pm 1 \mathrm{~min})(\mathrm{t}=2.72$; $p=0.04)$; VSF 2 and MSF $2(\mathrm{t}=3.19 ; p=0.01)$. Overall, for both species, MSF displayed a significantly lower entrance time relative to VSF, with the MSF 2 performing the best. 
(a)

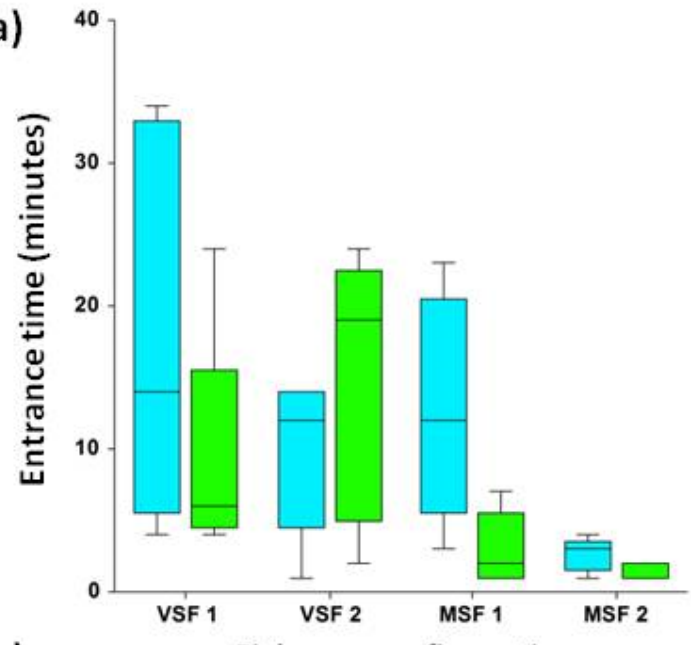

(b)

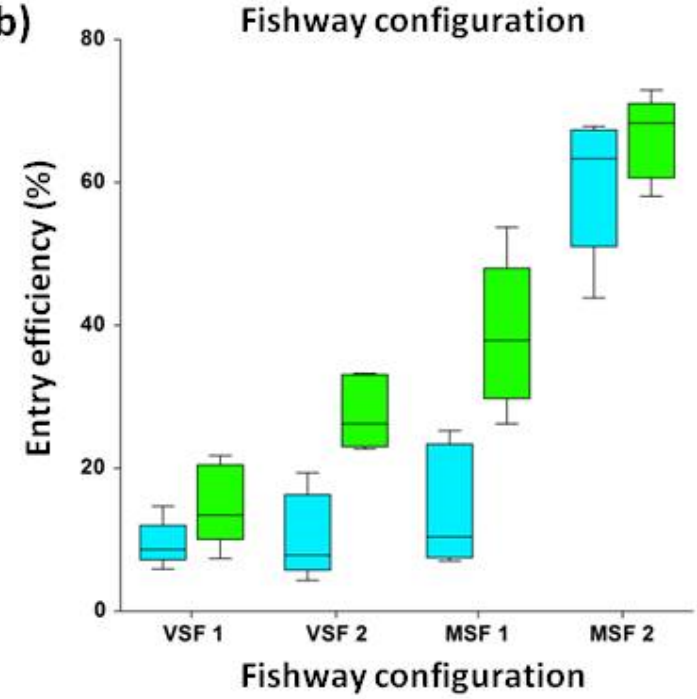

(c)

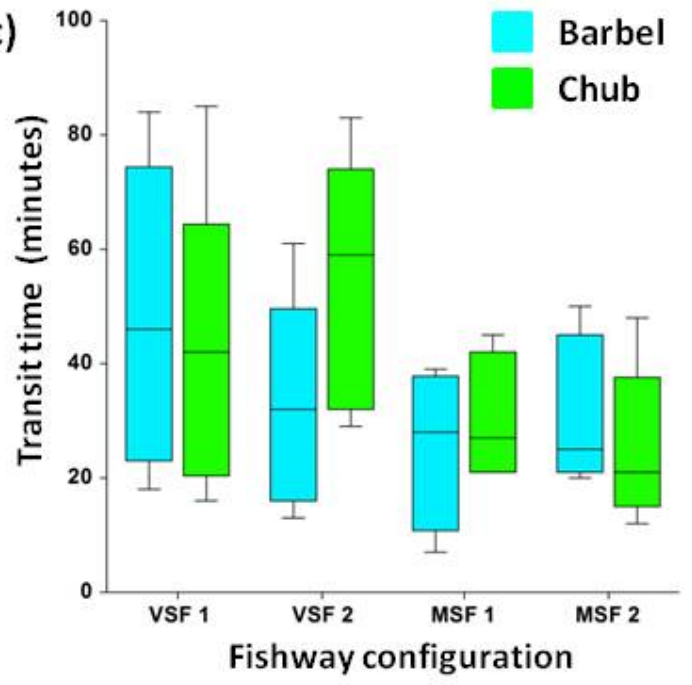

Figure 2. Luciobarbus bocagei (barbel) and Squalius pyrenaicus (chub) passage performance in the different fishway configurations tested: vertical slot fishway $(\mathrm{VSF}) 1-\mathrm{Q}=112 \mathrm{~L} \cdot \mathrm{s}^{-1}, \mathrm{VSF} 2-\mathrm{Q}=80 \mathrm{~L} \cdot \mathrm{s}^{-1}$; multislot fishway $(\mathrm{MSF}) 1-\mathrm{Q}=58 \mathrm{~L} \cdot \mathrm{s}^{-1}$, MSF $2-Q=37 \mathrm{~L} \cdot \mathrm{s}^{-1}$. (a) Entrance time-the time for the fastest fish to pass the first slot; (b) entry efficiency-the total number of fish passing the first slot divided by the number of corresponding attempts; (c) transit time-the time of the fastest fish reached the upstream end of the fishway. ( $Q$, discharge).

Concerning the entry efficiency (Figure 2b), PERMANOVA post hoc pairwise tests indicated differences for barbel performance between VSF 1 and MSF $2(t=10.99 ; p=0.001)$; VSF 2 and MSF $2(t=9.69 ; p=0.001)$; MSF 1 and MSF $2(t=7.93 ; p=0.001)$. While for the chub differences were found between VSF 1 and VSF $2(t=3.77 ; p=0.01)$; VSF 1 and MSF 1 $(\mathrm{t}=4.53 ; p=0.01)$; VSF 1 and MSF $2(\mathrm{t}=14.241 ; p=0.001)$; VSF 2 and MSF $2(\mathrm{t}=11.25$; $p=0.001)$; MSF 1 and MSF $2(t=5.23 ; p=0.002)$. Again, for both species, MSF were found to report a significantly higher entry efficiency than VSF, with the MSF 2 being the best one.

Regarding the transit times (Figure 2c), significant differences were found in the chub transit times negotiating the VSF 2 (median \pm SE: $59 \pm 10 \mathrm{~min}$ ) and MSF 2 (median \pm SE: $21 \pm 6 \mathrm{~min})(\mathrm{t}=2.47 ; p=0.04)$, with the latter displaying a lower transit time for successful negotiation. As for the barbel, no differences were found for the transit times between configurations. Additionally, comparing interspecific (barbel vs. chub) transit times, no differences were determined within each configuration tested.

In what concerns the hydraulics characterization of the four configurations tested (Table 2), for the same pool mean water depth, the MSF configurations operate with a lower discharge when compared to the VSF configurations, with the MSF 2 operating with less than 36,54 , and $67 \%$ of the discharge needed for the MSF 1, VSF 2, and VSF 1, respectively. 
Table 2. Numerical results, discharge, velocity, and turbulence parameters of the four fishway configurations tested considering the total water volume in a reference pool (pool n. ${ }^{\circ}$ ). $\mathrm{Q}$, discharge; $\mathrm{U}$ average, volume-averaged mean water velocity magnitude; $U$ max, maximum water velocity magnitude; TKE average, volume-averaged turbulent kinetic energy; TKE max, maximum turbulent kinetic energy; RSS average, volume-averaged Reynolds shear stress parallel to the bottom component; RSS max, maximum Reynolds shear stress parallel to the bottom component; VSF, vertical slot fishway; MSF, multislot fishway.

\begin{tabular}{ccccc}
\hline Fishway Configuration & VSF 1 & VSF 2 & MSF 1 & MSF 2 \\
\hline Q $\left(\mathrm{L} \cdot \mathrm{s}^{-1}\right)$ & 112 & 80 & 58 & 37 \\
U average $\left(\mathrm{m} \cdot \mathrm{s}^{-1}\right)$ & 0.58 & 0.35 & 0.26 & 0.19 \\
U max $\left(\mathrm{m} \cdot \mathrm{s}^{-1}\right)$ & 2.2 & 1.9 & 1.4 & 1.4 \\
TKE average $\left(\mathrm{m}^{2} \cdot \mathrm{s}^{-2}\right)$ & 0.054 & 0.042 & 0.026 & 0.016 \\
TKE max $\left(\mathrm{m}^{2} \cdot \mathrm{s}^{-2}\right)$ & 0.34 & 0.35 & 0.12 & 0.18 \\
RSS average $(\mathrm{Pa})$ & 10.3 & 8.2 & 5.1 & 3.4 \\
RSS max $(\mathrm{Pa})$ & 145 & 147 & 52 & 55 \\
\hline
\end{tabular}

Figure 3 shows the mean velocity magnitude and 2D time-averaged streamline patterns at $25 \% \mathrm{~h}_{m}$ for the four tested configurations. VSF configurations (Figure 3a,b) show higher average velocities when compared with MSFs (Figure 3c,d). Both VSFs have a sinusoidal flow pattern, even though they are fitted with aligned slots (see $[10,16,34]$ for the explanation). This flow pattern creates two large recirculation areas of lower velocitiesone smaller, adjacent to the upstream cross-wall, and one larger, in the center of the pool. The decrease in flow, and changes in configuration between VSF 1 and VSF 2, leads to a general flow velocity reduction and to a decrease in the size of the smaller recirculation area; however, an increase in the size of the larger recirculation area occurs, and the velocity gradients are also reduced from VSF 1 to VSF 2. MSFs have overall lower flow velocities. Their different configurations generate different flow patterns when compared with VSFsthe sinusoidal flow pattern is more pronounced as the flow makes a $90^{\circ}$ degree angle turn, at mid pool length, redirecting the flow from one sidewall to the other. There are two large recirculation areas within the main pool, and a small one near the entrance to the slot chamber, where a second small recirculation region is present.

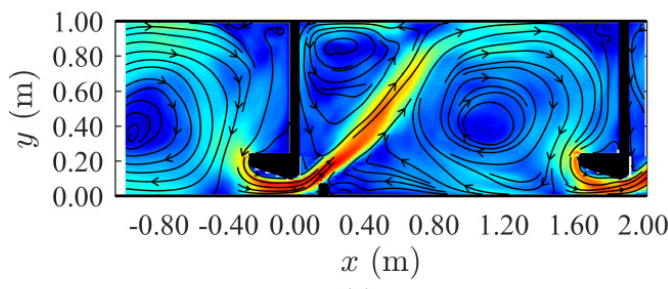

(a)

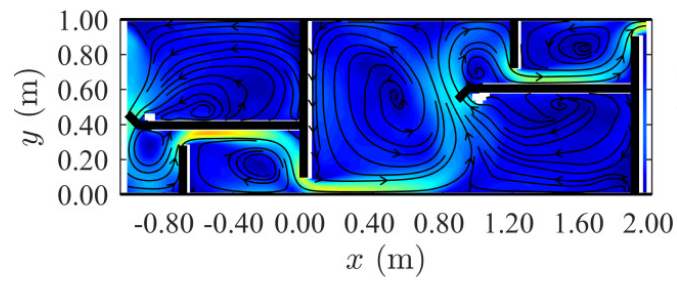

(c)

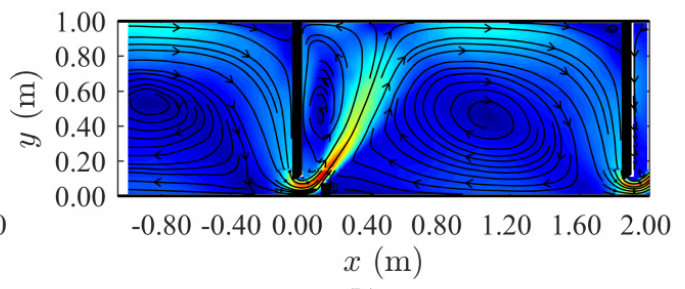

(b)

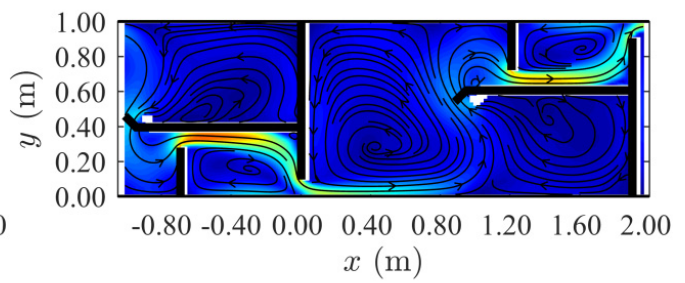

(d)

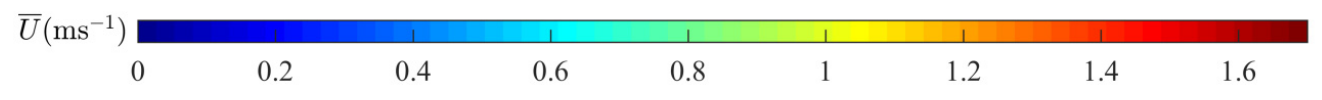

Figure 3. Mean velocity magnitude and 2D time-averaged streamline patterns at $0.2 \mathrm{~m}$ high from the bottom of the fishway (25\% $\mathrm{h}_{m}$ - pool mean water depth) in the four different fishway (VSF-vertical slot fishway; MSF-multislot fishway) configurations (VSF $1-\mathrm{Q}=112 \mathrm{~L} \cdot \mathrm{s}^{-1}$; VSF 2-Q $=80 \mathrm{~L} \cdot \mathrm{s}^{-1}$; MSF $1-\mathrm{Q}=58 \mathrm{~L} \cdot \mathrm{s}^{-1} ; \mathrm{MSF} 2-\mathrm{Q}=37 \mathrm{~L} \cdot \mathrm{s}^{-1}$ ): (a) VSF 1 ; (b) VSF 2; (c) MSF 1; (d) MSF 2. Figure produced with FLOW-3D ${ }^{\circledR}$ results. (Q, discharge). 


\section{Discussion}

Pool-type fishways are frequently the option applied to mitigate the impacts of instream structures obstructing river connectivity $[11,43]$. Among the several designs developed so far, VSFs are generally a consistent solution for river restoration managers, because they favor multi-species passage negotiation [13,44]. However, since VSFs generally require higher discharges to operate compared to pool-type fishways with bottom orifices and/or notches, operators may not share the same opinion, whereas they fail to meet one of the most challenging criteria in fishway design - the requirement to use as little water as possible for two main reasons: (i) construction costs are directly inflated with the design discharge; (ii) the more water volume is diverted, the less is available to hydropower production or other services provided by the dam, such as drinking water and irrigation [45]. Furthermore, in recent years, there has been a growing need to develop cost-effective fishways with lower turbulence that may operate with a broad discharge range [46]. In the present study, an experimental approach was conducted to assess entrance performance (entrance time and entry efficiency) and transit times of two Iberian cyprinids negotiating four distinct fishway configurations-using the same water depth in the pools-two VSFs and two MSFs, to gather insights about the fish passage behavior under different hydrodynamic scenarios and how conservation managers and dam operators may consider alternative mitigation cost-effective solutions capable of matching their goals.

Overall, the results from the fish experiments revealed that entrance performance, as described by entrance time and entry efficiency, was significantly higher-i.e., lower entrance time and higher entry efficiency - in MSFs (and particularly on MSF 2, which operates with the lowest discharge, $37 \mathrm{~L} \cdot \mathrm{s}^{-1}$ ) than in VSFs. In addition, transit time for successful negotiation was found to be significantly lower in MSFs than in VSFs, at least for the Iberian chub, a small resident water-column fish. Altogether, this means that MSF configurations (and particularly MSF 2) were clearly able to display a better performance in terms of entrance and transit time, comparatively to VSFs, making them a potential reliable technical solution to implement at river barriers, when water is a limiting factor, and physical site conditions do not allow the installation of nature-like fishways [47].

While discharge could stand as a determinant parameter driving the passage performance of these two cyprinids, other dependent factors, such as the flow patterns, velocity fields, and turbulence must be considered, as they play a major role in the assessment $[15,48-50]$. According to Quaresma et al. [34], the flow patterns are similar between VSF 1 and VSF 2 but change considerably when compared to MSF 1 [16] and MSF 2. This is mainly due to the fact that MSFs have a twofold number of slots per pool (which divides the head drop), but also because this type of fishway has slots organized in an offset position while both VSF configurations, VSF 1 and VSF 2, presented aligned slots; this implies that MSFs show a more pronounced meandering follow pattern than VSFs. MSF 1 and MSF 2 flow patterns are also dissimilar because MSF 2 was assembled as a hybrid solution composed of a bottom orifice and a vertical slot in each pool. This means that the flow pattern is clearly 3D (as described by Branco et al. [51], while characterizing the hydrodynamic conditions of a pool-type fishway equipped with notches and bottom orifices), differing from the quasi-2D pattern from the remaining configurations equipped only with vertical slots $[13,15,52]$. According to the numerical modeling results, maximum flow velocities were generated in the vicinity of the slots, whereas the higher magnitudes were found in VSFs, while MSFs showed velocities about 30\% lower (Table 2). However, even with relatively lower velocities, the attraction flow provided by the MSFs was able to drive both the stronger (barbel) and the weaker (chub) swimmers [53,54] to negotiate this type of fishway and accomplish even lower transit times.

Regarding turbulence, VSFs generated the maximum magnitudes, whereas both MSFs revealed much lower values: 70\% difference in Reynolds shear stress for VSF 1 compared to MSF 2 and 48\% in turbulent kinetic energy, respectively (Table 2). This means that fish encountered more predictable flows during MSF passage negotiation, 
which according to Liao [55], enhances fish exploratory movements and reduces their locomotion costs. Contrarily, according to the same author, turbulent flows with chaotic and wide fluctuations in velocity can repel fish and, consequently, increase their transit times. Moreover, pool areas with low velocities and turbulent magnitudes theoretically provide favorable hydrodynamic conditions for sustained swimming [49,56], allowing fish to rest in these areas before progressing through the fishway [57]. In addition, as described by Quaresma et al. [34], more than 90\% of the pool volume of the MSF 1 holds lower flow velocities than the critical swimming $\left(\mathrm{U}_{\text {crit }}\right)$ thresholds of Iberian fish, such as the potamodromous Iberian straight-mouth nase (mean $\mathrm{U}_{\text {crit }}=0.78 \mathrm{~m} \cdot \mathrm{s}^{-1}$ Pseudchondrostoma polylepis, Steindachner, 1864) [54] and Iberian barbel (mean $\mathrm{U}_{\text {crit }}=0.81 \mathrm{~m} \cdot \mathrm{s}^{-1}$ ) [53], but also for resident species such as the North Iberian chub (mean $\mathrm{U}_{\text {crit }}=0.54 \mathrm{~m} \cdot \mathrm{s}^{-1}$ Squalius carolitertii, Doadrio 1988) [54], a sister species of the South Iberian chub, with similar swimming capacity.

In terms of management implications, the MSFs offer an alternative option to restoring longitudinal connectivity comparatively to VSFs, currently viewed as one of the best types of technical pool-type fishway. This cost-effective solution allows stakeholders or barrier owners to save around 30 to $50 \%$ more water for fishway operation and should be taken into account as an effective fishway option [16], which allows for eco-efficiently enhancing the hydropower production or other water services provided by the barrier, such as irrigation or drinking water [10]. In dry regions such as in the Iberian Peninsula or other Mediterranean systems, this type of facility would be useful at river basins subject to long periods with low flows. Furthermore, it is likely to be an ever-increasing option in the near future, considering the rising scenarios of drought due to climate change $[25,58]$. Between both MSF configurations tested in this study, a major concern should be addressed-the probability of clogging with woody debris, sediments, or other materials transported by the river, particularly for configuration MSF 2, because it holds a bottom orifice, which is likely to become clogged and, consequently, completely compromise the operation of the facility. On the other hand, in VSFs, the probability of clogging is rather lower, making this type of fishway more reliable [11]. However, maintenance and monitoring are a key step to securing the correct functioning of any fish passage facilities and, therefore, should never be overlooked [5]. From this point forward, testing steeper slopes in multislot fishways could be an encouraging opportunity to determine if this type of facility could reduce the construction costs even more without compromising its efficiency for migrating fish.

\section{Conclusions}

The present study aimed to compare two widely used vertical slot fishways designs (VSF 1 and VSF 2) with recently developed multislot fishways (MSF 1 and MSF 2). For this, the transit time and entrance performance (entry efficiency and entrance time) of two cyprinids were assessed in four fishway configurations in a full-scale model under laboratory conditions. A numerical model previously verified and validated with experimental measurements was used to characterize the hydrodynamic conditions. Fish experiments highlighted that transit times tend to decrease, while negotiating MSF designs and entrance performance was effectively higher in this type of fishway compared to VSFs, which operate with higher discharges and revealed much higher turbulences. In conclusion, the MSFs stand out as an alternative cost-effective fishway solution for managers or practitioners working in river connectivity enhancement. This type of facility should be particularly useful in river systems subjected periodically to periods with low flows, since the operating discharge may reach a difference of $30-50 \%$ compared to VSFs, currently viewed as one of the best types of technical fishway. Finally, further studies should be conducted in the laboratory and in the field with these innovative cost-effective fishways, based on site-specific characteristics, encompassing multiple species and their swimming thresholds, to evaluate if these fishways may represent a holistic solution capable of assuring adequate up-and-downstream transposing for diadromous, potamodromous, and resident fish. 
Author Contributions: All authors listed have contributed substantially to the manuscript to be included as authors. Conceptualization, F.R., A.L.Q., P.B., and A.N.P.; methodology, F.R., A.L.Q., P.B., and J.M.S.; formal analysis, F.R. and A.L.Q.; investigation, F.R., P.B., S.D.A., J.M.S., and A.N.P.; writing-original draft preparation, F.R., A.L.Q., J.M.S., and P.B.; writing—review and editing, F.R., J.M.S., S.D.A., A.L.Q., P.B., and A.N.P.; supervision, P.B. and A.N.P. All authors have read and agreed to the published version of the manuscript.

Funding: Filipe Romão was funded by a grant (PD/BD/52512/2014) from Fundação para a Ciência e Tecnologia I.P. (FCT), Portugal. Susana D. Amaral was funded by a PhD grant from University of Lisbon/Santander Totta (SantTotta/BD/RG2/SA/2011), and by FCT (SFRH/BD/110562/2015). José M. Santos was supported by national funds via FCT under the "CEEC Institucional" 2018 program (Ref. 2/ISA/FCT/2018), and Paulo Branco is financed by national funds via FCT, under “Norma Transitória-DL57/2016/CP1382/CT0020. The Forest Research Centre (CEF) is a research unit funded by FCT (UIDB/00239/2020).

Institutional Review Board Statement: Not applicable.

Informed Consent Statement: Not applicable.

Data Availability Statement: The data presented in this study is contained and it is available within the article.

Acknowledgments: The authors would like to thank to the staff of the National Laboratory for Civil Engineering (LNEC) for all the support during the experiments. We would also like to thank the Institute for Nature Conservation and Forests (ICNF), which provided the necessary fishing and handling permits.

Conflicts of Interest: The authors declare no conflict of interest. The founding sponsors had no role in the design of the study; in the collection, analyses, or interpretation of data; in the writing of the manuscript, and in the decision to publish the results.

\section{References}

1. Dudgeon, D.; Arthington, A.H.; Gessner, M.O.; Kawabata, Z.-I.; Knowler, D.J.; Lévêque, C.; Naiman, R.J.; Prieur-Richard, A.-H.; Soto, D.; Stiassny, M.L.J.; et al. Freshwater biodiversity: Importance, threats, status and conservation challenges. Biol. Rev. 2006, 81, 163-182. [CrossRef] [PubMed]

2. AMBER: Adaptive Management of Barriers in European Rivers. Available online: http://www.amber.international (accessed on 5 August 2020).

3. Katopodis, C. Developing a toolkit for fish passage, ecological flow management and fish habitat works. J. Hydraul. Res. 2005, 43, 451-467. [CrossRef]

4. Santos, J.M.; Silva, A.; Katopodis, C.; Pinheiro, P.; Pinheiro, A.; Bochechas, J.; Ferreira, M.T. Ecohydraulics of pool-type fishways: Getting past the barriers. Ecol. Eng. 2012, 48, 38-50. [CrossRef]

5. Clay, C.H. Design of Fishways and Other Fish Facilities, 2nd ed.; Taylor \& Francis Group: Oxfordshire, UK, 2017; p. 256. [CrossRef]

6. Katopodis, C.; Williams, J.G. The development of fish passage research in a historical context. Ecol. Eng. 2012, 28, 407-417. [CrossRef]

7. Nilsson, C.; Reidy, C.A.; Dynesius, M.; Revenga, C. Fragmentation and flow regulation of the world's large river systems. Science 2005, 308, 405-408. [CrossRef] [PubMed]

8. Pegram, G.; Li, Y.; Le Quesne, T.; Speed, R.; Li, J.; Shen, F. River Basin Planning: Principles, Procedures and Approaches for Strategic Basin Planning; UNESCO: Paris, France, 2013; p. 181.

9. Zarfl, C.; Lumsdon, A.E.; Berlekamp, J.; Tydecks, L.; Tockner, K. A global boom in hydropower dam construction. Aquat. Sci. 2015, 77, 161-170. [CrossRef]

10. Romão, F.; Quaresma, A.L.; Santos, J.M.; Branco, P.; Pinheiro, A.N. Cyprinid passage performance in an experimental multislot fishway across distinct seasons. Mar. Freshw. Res. 2019, 70, 881-890. [CrossRef]

11. FAO/Dvwk. Fish Passes_Design, Dimensions and Monitoring; FAO: Rome, Italy, 2002; p. 119.

12. Valbuena-Castro, J.; Fuentes-Pérez, J.F.; García-Vega, A.; Bravo-Córdoba, F.J.; Ruiz-Legazpi, J.; de Azagra Paredes, A.M.; Sanz-Ronda, F.J. Coarse fishway assessment to prioritize retrofitting efforts: A case study in the Duero River basin. Ecol. Eng. 2020, 155, 105946. [CrossRef]

13. Romão, F.; Quaresma, A.L.; Branco, P.; Santos, J.M.; Amaral, S.; Ferreira, M.T.; Katopodis, C.; Pinheiro, A.N. Passage performance of two cyprinids with different ecological traits in a fishway with distinct vertical slot configurations. Ecol. Eng. 2017, 108, 180-188. [CrossRef]

14. Fuentes-Pérez, J.F.; Sanz-Ronda, F.J.; de Martínez Azagra Paredes, A.; García-Vega, A. Modeling water-depth distribution in vertical-slot fishways under uniform and nonuniform scenarios. J. Hydraul. Eng. 2014, 140, 06014016. [CrossRef] 
15. Liu, M.; Rajaratnam, N.; Zhu, D.Z. Mean flow and turbulence structure in vertical slot fishways. J. Hydraul. Eng. 2006, 132, 765-777. [CrossRef]

16. Romão, F.; Branco, P.; Quaresma, A.L.; Amaral, S.D.; Pinheiro, A.N. Effectiveness of a multi-slot vertical slot fishway versus a standard vertical slot fishway for potamodromous cyprinids. Hydrobiologia 2018, 816, 153-163. [CrossRef]

17. Mader, H.; Brandl, A.; Käfer, S. Design and Function Monitoring of an Enature ${ }^{\circledR}$ Vertical Slot Fish Pass in a Large Potamal River in Carinthia/Austria. Water 2020, 12, 551. [CrossRef]

18. Cooke, S.J.; Hinch, S.G. Improving the reliability of fishway attraction and passage efficiency estimates to inform fishway engineering, science, and practice. Ecol. Eng. 2013, 58, 123-132. [CrossRef]

19. Lucas, M.C.; Baras, E. Migration of Freshwater Fishes, 1st ed.; Blackwell Science Ltd.: Oxford, UK, $2001 ;$ p. 440.

20. Thiem, J.D.; Dawson, J.W.; Hatin, D.; Danylchuk, A.J.; Dumont, P.; Gleiss, A.C.; Wilson, P.; Cooke, S.J. Swimming activity and energetic costs of adult lake sturgeon during fishway passage. J. Exp. Biol. 2016, 219, 2534-2544. [CrossRef]

21. Lennox, R.J.; Paukert, C.; Aarestrup, K.; Auger-Méthé, M.; Baumgartner, L.; Birnie-Gauvin, K.; Davidsen, J.G. One hundred pressing questions on the future of global fish migration science, conservation, and policy. Front. Ecol. Evol. 2019, 7, 286. [CrossRef]

22. Birnie-Gauvin, K.; Aarestrup, K.; Riis, T.M.; Jepsen, N.; Koed, A. Shining a light on the loss of rheophilic fish habitat in lowland rivers as a forgotten consequence of barriers, and its implications for management. Aquat. Conserv. 2017, 27, 1345-1349. [CrossRef]

23. Santos, J.M.; Rivaes, R.; Boavida, I.; Branco, P. Structural microhabitat use by endemic cyprinids in a Mediterranean-type river: Implications for restoration practices. Aquatic Conserv Mar Freshw. Ecosyst. 2018, 28, 26-36. [CrossRef]

24. Boix, D.; García-Berthou, E.; Gascón, S.; Benejam, L.; Tornés, E.; Sala, J.; Benito, J.; Munné, A.; Solà, C.; Sabater, S. Response of community structure to sustained drought in Mediterranean rivers. J. Hydrol. 2010, 383, 135-146. [CrossRef]

25. Kingsford, R.T. Conservation management of rivers and wetlands under climate change-A synthesis. Mar. Freshwater Res. 2011, 62, 217-222. [CrossRef]

26. Silva, A.T.; Lucas, M.C.; Castro-Santos, T.; Katopodis, C.; Baumgartner, L.J.; Thiem, J.D.; Aaretrup, K.; Pompeu, P.S.; O’Brien, G.C.; Braun, D.C.; et al. The future of fish passage science, engineering, and practice. Fish Fish. 2017, 19, 340-362. [CrossRef]

27. Smith, K.G.; Darwall, W.R. The status and distribution of freshwater fish endemic to the Mediterranean Basin. In IUCN Red list of Threatened Species; IUCN: Gland, Switzerland; Cambridge, UK, 2006; Volume 1, 34p.

28. Miranda, R.; Pino-del-Carpio, A. Analyzing freshwater fish biodiversity records and respective conservation areas in Spain. J. Appl. Ichthyol. 2016, 32, 240-248. [CrossRef]

29. Branco, P.; Segurado, P.; Santos, J.M.; Pinheiro, P.J.; Ferreira, M.T. Does longitudinal connectivity loss affect the distribution of freshwater fish? Ecol. Eng. 2012, 48, 70-78. [CrossRef]

30. Tummers, J.S.; Hudson, S.; Lucas, M.C. Evaluating the effectiveness of restoring longitudinal connectivity for stream fish communities: Towards a more holistic approach. Sci. Total Environ. 2016, 569, 850-860. [CrossRef] [PubMed]

31. Rajaratnam, N.; Katopodis, C.; Solanki, S. New designs for vertical slot fishways. Can. J. Civ. Eng. 1992, 19, 402-414. [CrossRef]

32. Tauber, M.; Mader, H. Development of an Economical and Ecological Optimized Multi Slot Fish Pass. In Proceedings of the Small Hydro 2009, Vancouver, BC, Canada, 28-29 April 2009.

33. Tauber, M.; Mader, H. Hydraulic comparison of standard vertical slot and multi structure slot fish bypass. In Proceedings of the 1st European IAHR Congress, Edinburgh, UK, 4-6 May 2010.

34. Quaresma, A.L.; Romão, F.; Branco, P.; Ferreira, M.T.; Pinheiro, A.N. Multi slot versus single slot pool-type fishways: A modelling approach to compare hydrodynamics. Ecol. Eng. 2018, 122, 197-206. [CrossRef]

35. Fuentes-Pérez, J.F.; Tuhtan, J.A.; Eckert, M.; Romão, F.; Ferreira, M.T.; Kruusmaa, M.; Branco, P. Hydraulics of Vertical-Slot Fishways: Nonuniform Profiles. J. Hydraul. Eng. 2019, 145, 06018020. [CrossRef]

36. [CEN] European Committee for Standardization. Water Quality: Sampling of Fish with Electricity; European Standard EN 14011: 2003 E; CEN: Brussels, Belgium, 2003.

37. Plaut, I. Critical swimming speed: Its ecological relevance. Comp. Biochem. Physiol. A 2001, 131, 41-50. [CrossRef]

38. Amaral, S.D.; Branco, P.; Romão, F.; Viseu, T.; Ferreira, M.T.; Pinheiro, A.N.; Santos, J.M. The effect of weir crest width and discharge on passage performance of a potamodromous cyprinid. Mar. Freshw. Res. 2018, 69, 1795-1804. [CrossRef]

39. Mallen-Cooper, M. Swimming ability of adult golden perch, Macquaria ambigua (Percichthyidae), and adult silver perch, Bidyanus bidyanus (Teraponidae), in an experimental vertical-slot fishway aust. J. Mar. Freshw. Res. 1994, 45, 191-198. [CrossRef]

40. Anderson, M.J. Permutational Multivariate Analysis of Variance (PERMANOVA); Statistics Reference Online; Wiley StatsRef, John Wiley \& Sons: Hoboken, NJ, USA, 2017. [CrossRef]

41. Anderson, M.J. A new method for non-parametric multivariate analysis of variance. Austral. Ecol. 2001, 26, 32-46. [CrossRef]

42. Anderson, M.J.; Gorley, R.N.; Clarke, K.R. PERMANOVA+ For PRIMER: Guide to Software and Statistical Methods; PRIMER-E: Plymouth, UK, 2008.

43. Linnansaari, T.; Wallace, B.; Curry, R.; Yamazaki, G. Mactaquac Aquatic Ecosystem Study Report Series 2015-016, Fish Passage in Large Rivers: A literature Review; Canadian Rivers Institute: New Brunswick, CA, Canada, 2015.

44. Sanz-Ronda, F.J.; Bravo-Córdoba, F.J.; Sánchez-Pérez, A.; García-Vega, A.; Valbuena-Castro, J.; Fernandes-Celestino, L.; Torralva, M.; Oliva-Paterna, F.J. Passage Performance of Technical Pool-Type Fishways for Potamodromous Cyprinids: Novel Experiences in Semiarid Environments. Water 2019, 11, 2362. [CrossRef] 
45. Williams, J.G.; Amstrong, G.; Katopodis, C.; Larinier, M.; Travade, F. Thinking like a fish: A key ingredient for development of effective fish passage facilities at river obstructions. River Res. Appl. 2012, 28, 407-417. [CrossRef]

46. Baumgartner, L.J.; Boys, C.; Marsden, T.; McPherson, J.; Ning, N.; Phonekhampheng, O.; Robinson, W.; Singhanouvong, D.; Stuart, I.G.; Thorncraft, G. A Cone Fishway Facilitates Lateral Migrations of Tropical River-Floodplain Fish Communities. Water 2020, 12, 513. [CrossRef]

47. Tamario, C.; Degerman, E.; Donadi, S.; Spjut, D.; Sandin, L. Nature-like fishways as compensatory lotic habitats. River Res Applic. 2018, 34, 253-261. [CrossRef]

48. Cea, L.; Pena, L.; Puertas, J.; Vazquez-Cendon, M.E.; Pena, E. Application of several depth-averaged turbulence models to simulate flow in vertical slot fishways. J. Hydraul. Eng. 2007, 133, 160-172. [CrossRef]

49. Domenici, P.; Kapoor, B.G. Fish Locomotion: An Eco-Ethological Perspective, 1st ed.; Taylor \& Francis Group: Boca Raton, FL, USA, 2010; p. 549. [CrossRef]

50. Elder, J.; Coombs, S. The influence of turbulence on the sensory basis of rheotaxis. J. Com. Physiol. A 2015, 201, 667-680. [CrossRef]

51. Branco, P.; Santos, J.M.; Katopodis, C.; Pinheiro, A.; Ferreira, M.T. Pool-type fishways: Two different morpho-ecological cyprinid species facing plunging and streaming flows. PLoS ONE 2013, 8, e65089. [CrossRef]

52. Bermúdez, M.; Puertas, J.; Cea, L.; Pena, L.; Balairón, L. Influence of pool geometry on the biological efficiency of vertical slot fishways. Ecol. Eng. 2010, 36, 1355-1364. [CrossRef]

53. Mateus, C.S.; Quintella, B.R.; Almeida, P.R. The critical swimming speed of Iberian barbel Barbus bocagei in relation to size and sex. J. Fish Biol. 2008, 73, 1783-1789. [CrossRef]

54. Romão, F.; Quintella, B.R.; Pereira, T.J.; Almeida, P.R. Swimming performance of two Iberian cyprinids: The Tagus nase Pseudochondrostoma polylepis (Steindachner, 1864) and the bordallo Squalius carolitertii (Doadrio, 1988). J. Appl. Ichthyol. 2012, 28, 26-30. [CrossRef]

55. Liao, J.C. A review of fish swimming mechanics and behavior in altered flows. Philos. Trans. R. Soc. B 2007, 362, 1973-1993. [CrossRef] [PubMed]

56. Hammer, C. Fatigue and exercise tests with fish. Comp. Biochem. Physiol. A 1995, 112, 1-20. [CrossRef]

57. Mallen-Cooper, M.; Zampatti, B.; Stuart, I.; Baumgartner, L. Innovative fishways-Manipulating turbulence in the vertical-slot design to improve performance and reduce cost. In Report to the Murray-Darling Basin Commission by Fishway Consulting Services; Murray Darling Basin Authority: Sydney, Australia, 2008.

58. Field, C.B.; Barros, V.R.; Mach, K.; Mastrandrea, M. Climate Change 2014: Impacts, Adaptation, and Vulnerability. In Contribution of Working Group II to the Fifth Assessment Report of the Intergovernmental Panel on Climate Change; IPCC: Geneva, Switzerland, 2014. 